\title{
A New, Sensitive and Disposable Electrochemical Immunosensor Based on Benzaldehyde Side Group Containing Phosphazene Polymer Modified ITO Substrate for Interleukin $1 \beta$ Detection
}

\section{Interlökin $1 \beta$ Tespiti için Benzaldehit Yan Grup İçeren Fosfazen Polimer ile Modifiye Edilmiş ITO Substrat Temelli Yeni, Hassas ve Tek Kullanımlık Bir Elektrokimyasal İmmünosensör}

\section{Muhammet Aydın}

Tekirdağ Namık Kemal University, Scientific and Technological Research Center, Tekirdağ, Turkey.

\section{ABSTRACT}

\begin{abstract}
In this study, a novel electrochemical ultrasensitive immunosensor based on disposable benzaldehyde substituted phosp hazene polymer (BSPP) modified ITO electrode was developed for interleukin $1 \beta$ (IL 1B) detection. Aldehyde side groups containing phosphazene polymer (BSPP) synthesized via ring opening polymerization method. These aldehyde groups provided anchoring points for anti-IL $1 \beta$ antibodies. The production process of the proposed immunosensor was monitored by electrochemical techniques like Electrochemical Impedance Spectroscopy (EIS) and Cyclic Voltammetry (CV). In addition, these fabrication steps were characterized by utilizing Scanning Electron Microscopy (FE-SEM) and Atomic Force Microscopy (AFM). Moreover, BSPP polymer layer on the polymer coated electrode surface was investigated by using Energy Dispersive X-ray (EDX). The fabricated immunosensor had a low detection limit $(9.3 \mathrm{fg} / \mathrm{mL})$ and a wide linear detection range (0.03-7.5 pg/mL). Moreover, it had good reproducibility (1.82\%), excellent repeatability (1.56\%), good selectivity and high stability. The results of experiments showed that the BSPP polymer was desirable platform for IL $1 \beta$ antigen detection in clinical diagnosis and practical applications. The applicability of the suggested biosensor was tested by measuring IL $1 \beta$ level in human serum and the suggested immunosensor had acceptable results for quantitative analysis.
\end{abstract}

\section{Key Words}

Poly(phosphazene), label free immunosensor, electrochemical impedance spectroscopy, interleukin 1ß (IL 1ß).

\section{öz}

u çalışmada, interlökin $1 \beta$ (IL 1B) tespiti için tek kullanımlık benzaldehit ikameli fosfazen polimeri (BSPP) ile modifiye edilmiş ITO elektrot temelli yeni bir elektrokimyasal ultrahassas immünosensör geliştirilmiştir. Aldehit yan grupları içeren fosfazen polimeri (BSPP) halka açma polimerizasyonu yöntemi ile sentezlenmiştir. Bu aldehit grupları, anti-IL $1 \beta$ antikorları için bir bağlantı noktaları sağlamıştır. Önerilen immünosensörün üretim süreci, Elektrokimyasal Empedans Spektroskopisi (EIS) ve Döngüsel Voltammetri (CV) gibi elektrokimyasal tekniklerle izlendi. Ek olarak, bu üretim aşamaları, Taramalı Elektron Mikroskobu (FE-SEM) ve Atomik Kuvvet Mikroskobu (AFM) kullanılarak karakterize edildi. Ayrıca, polimer kaplı elektrot yüzeyindeki BSPP polimer tabakası, Enerji Dağıtııı X-ışını (EDX) kullanılarak araştırıldı. Üretilen immünosensör düşük bir tespit sınırına (9.3 fg / mL) ve geniş bir doğrusal tayin aralığına (0.03-7.5 pg / mL) sahiptir. Ayrıca, iyi tekrarlanabilirlik (\%1.82), mükemmel tekrarlanabilirlik (\%1.56), iyi seçicilik ve yüksek stabiliteye sahipti. Deney sonuçları, BSPP polimerinin, klinik teşhis ve pratik uygulamalarda IL1 $\beta$ antijen tespiti için arzu edilen bir platform olduğunu gösterdi. Önerilen biyosensörün uygulanabilirliği, insan serumunda IL $1 \beta$ seviyesi ölçülerek test edildi ve önerilen immünosensör, nicel analiz için kabul edilebilir sonuçlara sahipti.

\footnotetext{
Anahtar Kelimeler

Poli(fosfazen), label free immunosensor, electrokimyasal impedans spectroskopi, interleukin $1 \beta$ (IL 1ß). 


\section{INTRODUCTION}

R apid and accurate detection of tumor biomarkers is important for early detection of cancer. In recent years, enzyme-linked immunosorbent assay and chemiluminescence immunoassay have been employed for IL $1 \beta$ detection. These methods require expensive devices and long operation procedure. Because of these disadvantages, a sensitive and rapid method is required for IL $1 \beta$ biomarker detection. Specific binding between antiIL $1 \beta$ antibody and IL $1 \beta$ antigen is the key strategy for rapid detection of this biomarker by using low cost, sensitive and selective immunosensor. Recently, label-free electrochemical immunosensors are promising tools owing to easy fabrication process and rapid detection of several analytes. The design of a biosensor matrix is important and different types of materials are utilized as immobilization matrices. Polymers have significant roles in the fabrication of electrochemical biosensors. They had a lot of end groups and they provide more antibody loading on the biosensor surface.

Polyphosphazenes are members of the polymer family having an inorganic backbone containing nitrogen and phosphorus atoms. In addition, the advantage of using these polymers is attachment of different substituents to phosphorus backbone. As a result of this attachment, these polymers have unique properties and they can use in different applications such as biomedical studies and drug delivery researches [1]. Furthermore, polyphosphazenes prevent the growth of bacteria and yeast cells and they are biodegradable. The backbone of the polyphosphazenes can be diversified easily by different functional site groups [2]. Therefore, they are promising immobilization matrices for biomolecules in biosensor applications.

Interleukin $1 \beta(I L-1 \beta)$ is a protein and it has a significant role in several biological functions like immune system. Its CDNA encodes a precursor protein of 269 amino acids. This polypeptide is firstly precursor protein and after that it turns to the $15-20 \mathrm{kDa}$ protein which is responsible for IL 1 activity[3]. IL $1 \beta$ is usually produced in macrophages, mucosa epithelial cells, acinar and ductal cells of the salivary glands. In addition, IL-1 $1 \beta$ is a biomarker in lung, colon and breast cancer, oral carcinoma and skin melanomas $[4,5]$. For the sensitive determination of IL-1 $\beta$, different biosensors with different modification strategies and detection techniques have been employed and these biosensors are compared in Table
1A. Krause et al. (2015) fabricated a microfluidic array amplified with magnetic beads and gold nanoparticles (AuNPs) for IL-1 $\beta$ and other cancer biomarkers determination to investigate mucositis risk in cancer patients [6]. A fiber-optic particle plasmon resonance sensor was developed by Chiang et al., and the detection principle was based on molecular binding of IL-1 $\beta$ to anti-IL$1 \beta$ conjugated AuNPs. The linear range and detection limit of this sensor were $0.05-10 \mathrm{ng} / \mathrm{mL}$ and $21 \mathrm{pg} / \mathrm{mL}$, respectively [7]. Baraket et al. (2017) fabricated a biosensor based on eight gold microelectrodes as working electrode placed onto silicon substrates. The linear range and detection limit of this biosensor were $1-15 \mathrm{pg} / \mathrm{mL}$ and $0.3 \mathrm{pg} / \mathrm{mL}$, respectively [8].

Electrochemical biosensors are gained interest in electroanalytical applications because of their good sensitivity, high stability, favorable specificity, and repeatability. The working principle of these biosensors is based on specific reaction between the target molecule and biorecognition molecule. As a result of this reaction, an electrical signal forms and this signal is associated to concentration of target molecule. Electrochemical impedance spectroscopy (EIS) is an useful tool to monitor of biosensing system. This method is usually employed for monitoring of modified electrode features during the fabrication procedure. An EIS biosensor system contains a biosensing element, which is immobilized on the working electrode and this biosensing element interacts with the target molecule. In EIS based immunosensors, antibodies are utilized as biorecognition molecules and they detect their antigens. This type immunosensors provide label free detection of target molecules $[9,10]$. In addition, ElS based immunosensors are ultrasensitive and low cost devices. The cost of a biosensor is based on utilized strategy during the fabrication $[10,11]$. The label-free strategy reduced the cost of immunosensor $[12,13]$. For the development of an immunosensor, different ways were utilized for working electrode fabrication.Drop casting, adsorption, electrophoretic deposition, electrochemical deposition are the techniques for biosensor fabrication. The utilized technique and materials increases the stability of the biosensor [14]. Spin-coating is a working electrode fabrication method that based on deposition of fluid on the electrode surface. In this method, uniform, reproducible and thin film is formed on the working electrode[15, 16]. This method is simple, but it is rarely employed for biosensor production. 
In this work, a sensitive and selective EIS based immunosensor was developed by using BSPP polymer with benzaldehyde side groups modified disposable ITO sheet for IL $1 \beta$ biomarker detection. These aldehyde groups were utilized for anchoring of anti-IL $1 \beta$ antibodies on the ITO sheet. For the modification of ITO sheet, spin-coating method was utilized. After modification of ITO sheets with benzaldehyde substituted poly(phosphazene), aldehyde groups were found on the ITO sheet. These aldehyde groups were attached to amino groups of antibodies directly. Consequently, bioelectrodes were prepared by using simple and easy way. In addition, EIS and cyclic voltammetry methods were employed for monitoring of electrode fabrication and immunosensor analytical performance. The repeatability, reproducibility and real serum applications were performed to investigate the performance of the suggested immunosensor. Furthermore, the accuracy of the proposed immunosensor was examined via standard addition method.

\section{MATERIALS and METHODS}

\section{Materials and Apparatus}

Phosphonitrilic chloride trimer $\left(\mathrm{P}_{3} \mathrm{~N}_{3} \mathrm{Cl}_{6}, 97 \%\right)$, 4-hydroxybenzaldehyde (98\%), Triethylamine (TEA, $\geq 99 \%$ ), Aluminum Chloride ( $\mathrm{AlCl} 3,99 \%)$ and Sodium metal rod, tetrahydrofuran (anhydrous, $\geq 99.9 \%$ ), Acetone $(\geq 99.9 \%)$, Chloroform, (max. 0.003\% $\mathrm{H}_{2} \mathrm{O}$ ), Methanol ( $\geq 99.9 \%)$ and Hexane $(95 \%)$ were obtained from Sigma-Aldrich and were employed in synthesis and purification processes. $\mathrm{K}_{4}\left[\mathrm{Fe}(\mathrm{CN})_{6}\right]$ and $\mathrm{K}_{3}\left[\mathrm{Fe}(\mathrm{CN})_{6}\right], \mathrm{KCl}$, $\mathrm{KH}_{2} \mathrm{PO}_{4}, \mathrm{~K}_{2} \mathrm{HPO}_{4}$ were from Sigma-Aldrich. Clear glass prescored ampoules ( $10 \mathrm{~mL} \times 108 \mathrm{~mm}$ ) were purchased from Wheaton ${ }^{\circledR}$ company. Indium tin oxide (ITO) coated PET sheets ( $2 \mathrm{~mm} \times 20 \mathrm{~mm}, 60 \Omega / \mathrm{cm} 2)$, Anti-IL $1 \beta$ antibody, and IL $1 \beta$ antigen were supplied by Sigma-Aldrich. These protein solutions were prepared using phosphate buffer (PBS 50 mM, pH 7.4).

\section{Chemical and Morphological Analyses}

Electrochemical analyses (CV and EIS) were performed via Gamry Potentiostat/Galvanostat Reference 1000 device. ITO sheet working electrode $(2 * 20 \mathrm{~mm})$, a platinum wire counter electrode, and an $\mathrm{Ag} / \mathrm{AgCl}$ reference electrode were used for electrochemical experiments. CVs were taken in a potential range from 0 to $500 \mathrm{mV}$ at a scan rate $100 \mathrm{mV} / \mathrm{s}$. EIS analyses were performed from $50 \mathrm{kHz}$ to $0.05 \mathrm{~Hz}$. Proton nuclear magnetic resonance (1H NMR) spectra were taken at a Varian UNITY INOVA
500. Fourier Transform Infrared (FTIR) analyses were taken by utilizing a Bruker Vertex 70 device in the range of 4000-400 $\mathrm{cm}^{-1}$. Dispersive Raman analyses were performed by using a Thermo Scientific DXR-Raman spectrometer with a 780-nm excitation laser. The morphological characterizations of the suggested immunosensor were made by using AFM, SEM and energy dispersive $X$-ray (EDX) devices. SEM images were recorded utilizing Scanning electron microscope (QUANTA FEG-250) with low vacuum detector. AFM images were recorded utilizing an Ambient AFM, NanoMagnetic Instrument. The images were taken in tapping AFM mode.

\section{Polymer Synthesis and Preparation of Modified ITO electrode immunosensor}

Benzaldehyde side groups containing polymer (BSPP) were synthesized (Scheme 1) and characterized according to our previous report [14]. The chemical characterizations results are given below.

FT-IR (ATR, cm $\left.{ }^{-1}\right): 2832 \quad\left(-\mathrm{CH}_{2}\right) ; 1695(\mathrm{C}=\mathrm{O}) ; 1598$, 1501(aromatic); 1195 (P=N); 1155 (P-O-C); 920 (P-O-Ph); 830. Raman ( $\lambda$ laser $\left.=780 \mathrm{~nm}, \mathrm{~cm}^{-1}\right): 3073,3000 ; 1696$ $(\mathrm{C}=\mathrm{O}) ;$ 1598, 1509 (aromatic); 1233, $1168(\mathrm{P}=\mathrm{N}) ; 1010$ (P-O-Ph); 718(PN). ${ }^{1} \mathrm{H}$ NMR (CDCl $\left.{ }_{3}, 400 \mathrm{MHz}\right)$ 8: 7,19ppm (Ha; 4H, ortho); 7,48ppm (Hb; 4H, meta); and 9,66ppm (Hc; $1 \mathrm{H}, \mathrm{CHO}$ ). ${ }^{31} \mathrm{P}$ NMR (DMSO-D6, $202.4 \mathrm{MHz}$ ): -5.3 ppm.

Scheme 1 contains the polymer synthesis steps, preparation of BSPP polymer coated ITO electrodes and the fabrication protocol of IL $1 \beta$ immunosensor.

Firstly, the disposable ITO electrodes were sonicated in ethanol, soap solution and ultrapure water, respectively. After that, polymer BSPP was solved in dry THF solvents utilizing ultrasonic bath for 15 minutes. Then, polymer BSPP was dropped on to the clean ITO sheet surface and spinned at 1000 rpm for 60 seconds. After this spin coating process, the polymer BSPP modified ITO electrode was washed with ultrapure water. Next, an anti-IL $1 \beta$ antibody solution was utilized for immersing the polymer BSPP modified ITO electrode and incubated there for $1 \mathrm{~h}$. In this step, antibodies immobilized electrode surface because of the existence of aldehyde groups of the polymer BSPP. After rinsing of anti-IL $1 \beta$ antibody attached ITO-PET electrode with ultrapure water. BSA solution was employed to block remaining aldehyde groups. Then, the prepared immunoelectrodes were immersed in various concentrations of IL $1 \beta$ solutions and incubated there for 1 hour. 


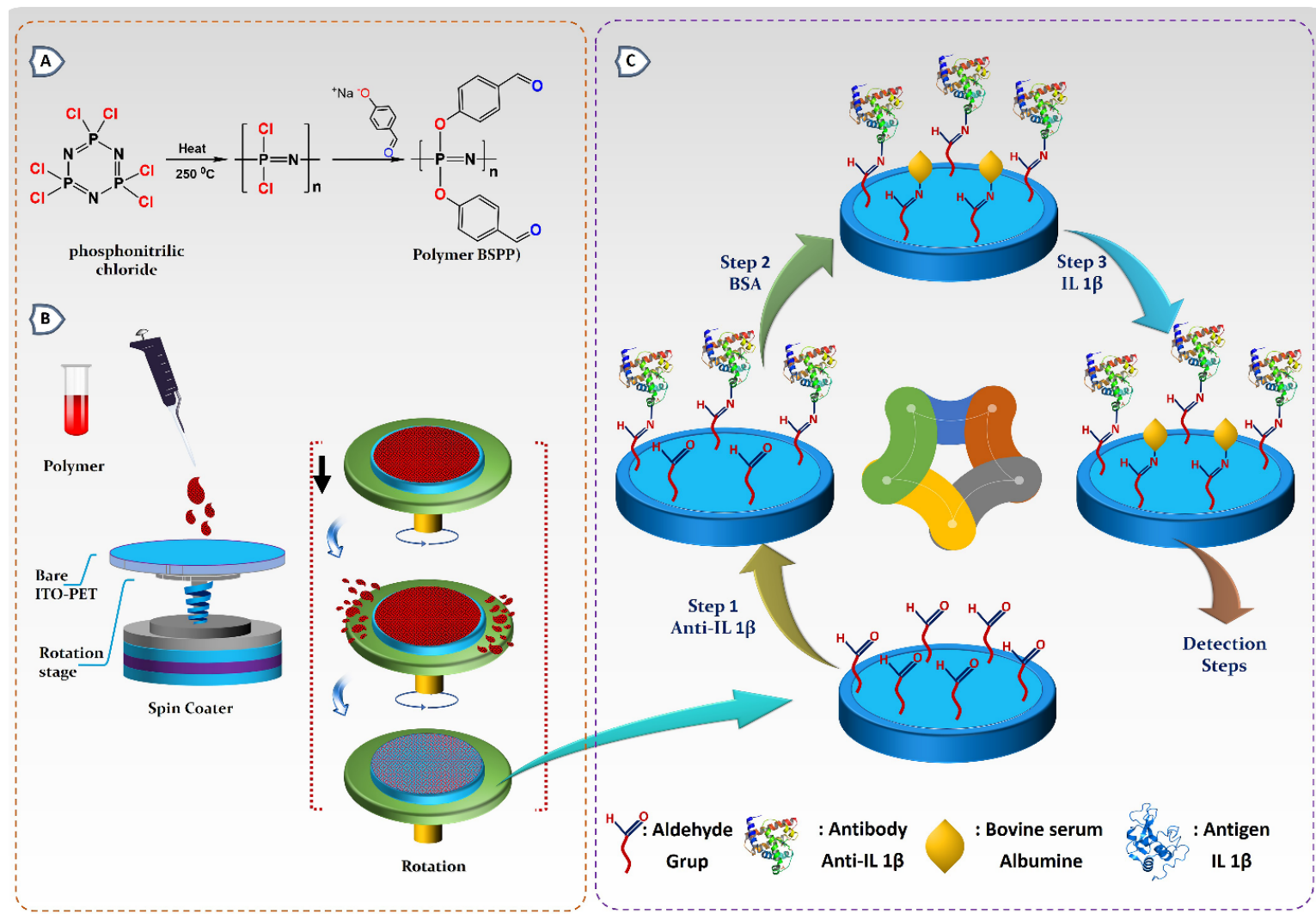

Sheme 1. (A) Synthesis pathway of Polymer BSPP, (B) Preparation of BSPP polymer coated ITO electrodes and (C) fabrication protocol of IL $1 \beta$ immunosensor.

\section{Real Serum Sample Measurements}

Human serum samples were supplied by the Tekirdağ Namık Kemal University Faculty of Medicine. These serum samples were examined by using the suggested biosensor after a 20 fold dilution with PBS. The accuracy of the suggested biosensor was studied by addition of IL $1 \beta$ antigen to the diluted human serum samples.

\section{RESULTS and DISCUSSION}

\section{Chemical Characterization of the ITO Electrode Surface}

Benzaldehyde substituted polymer (BSPP) were synthesized by reaction sequences with ring opening polymerization and replacement reactions. These reaction stages are shown in Scheme 1. The chemical structure of (BSPP) was monitored with different spectral methods (FTIR, RAMAN, $1 \mathrm{H}$ and 31P NMR) to display the BSPP synthesis procedure and spectroscopic results of this synthesis are illustrated our previous report [17].

The chemical bonds between BSPP polymer coated ITO substrate and anti- IL $1 \beta$ antibody was proved by using FTIR and DXR-RAMAN spectroscopic techniques.
The chemical bonds between BSPP polymer coated ITO substrate and anti- IL $1 \beta$ antibody was proved by using FTIR and DXR-RAMAN spectroscopic techniques. The FTIR spectra of polymer BSPP layer was taken after spin-coating procedure (green line) and after anti-IL $1 \beta$ antibody binding on the ITO-PET surface (purple line) are displayed in Fig. $1 \mathrm{~A}$ and $1 \mathrm{~B}$, respectively. As shown in Fig. 1A, the aldehyde substituted BSPP functionalized ITO electrode surface had the two absorption peaks at $1190 \mathrm{~cm}^{-1}$ and $830 \mathrm{~cm}^{-1}$ that proved the presence of $\mathrm{P}=\mathrm{N}$ and $\mathrm{P}-\mathrm{N}$ bonds in polymer [18-21]. The strong signal observed around $1695 \mathrm{~cm}^{-1}$ was proved that $\mathrm{C}=0$ stretching vibration of aldehyde side groups of polymer BSPP [10]. In addition, the peak around at $920 \mathrm{~cm}^{-1}$ was indicated the $\mathrm{P}-\mathrm{O}-\mathrm{Ph}$ stretching vibration of side groups $[22,23]$. The basic functional groups of protein structure are $-\mathrm{NH}$ and $-\mathrm{OH}$ bands $(3000-3700 \mathrm{~cm}-1)$. As seen red line in Fig. 1B, there were broad and intense bands for amide I at $1648 \mathrm{~cm}^{-1}$ and for amide II at $1542 \mathrm{~cm}^{-1}$, and this showed the anchoring of the anti- IL $1 \beta$ antibody to polymer BSPP $[17,24]$. The chemical structure of polymer BSPP coated ITO-PET electrode and anti-IL $1 \beta$ antibody attached ITO substrate was investigated via 

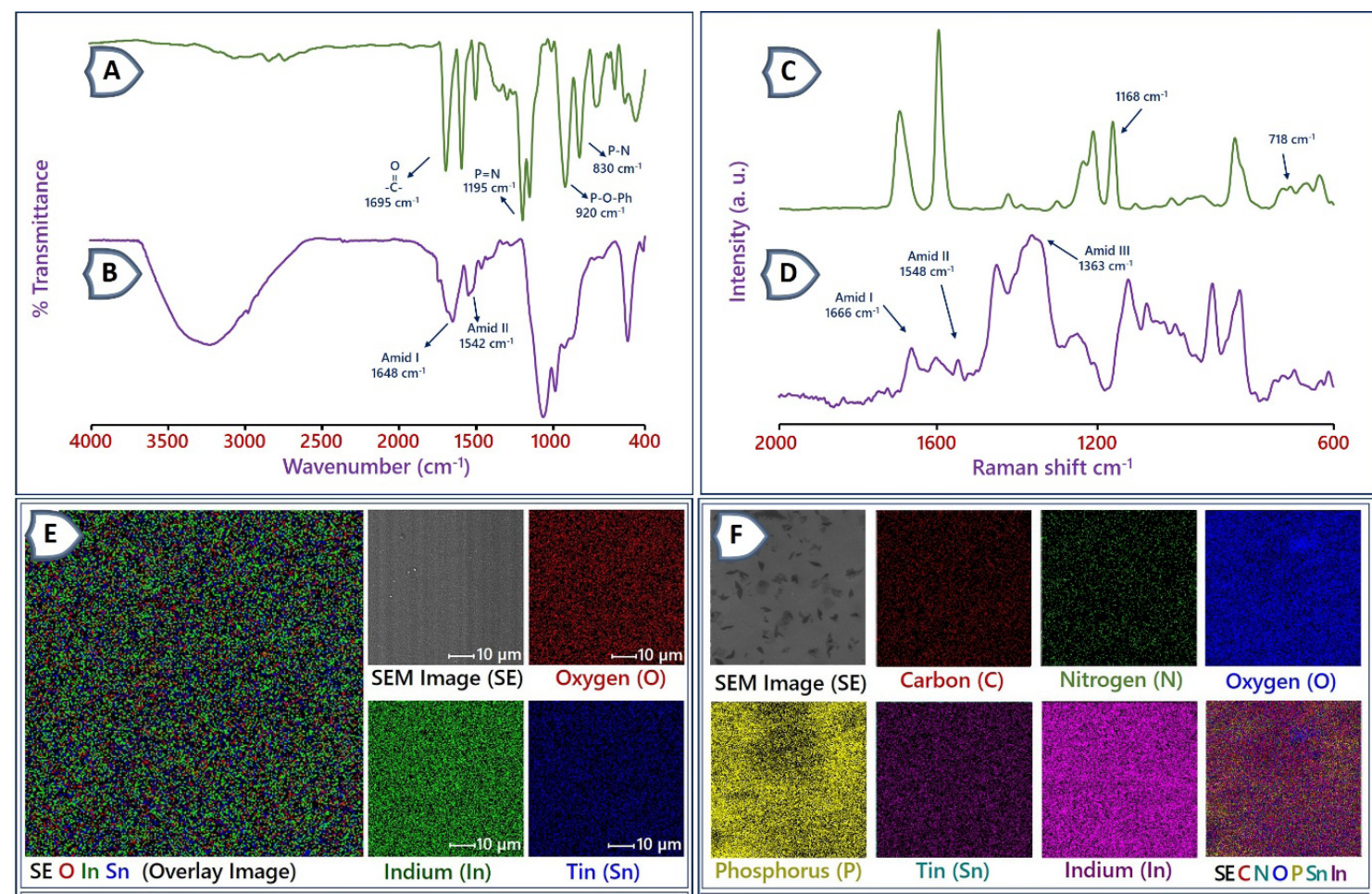

Carbon (C)

Nitrogen $(\mathrm{N})$

Oxygen (O)
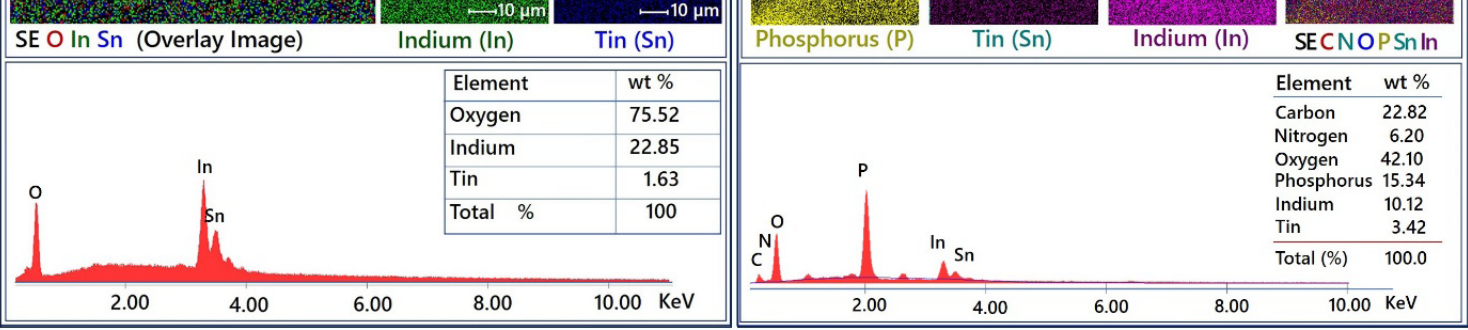

Figure 1. FTIR and Raman spectra of polymer BSPP ( $A$ and $C$ ) and anti- IL $1 \beta$ antibody immobilized subatrate (B and D) and SEM-EDX elementel spectra and mapping of bare and BSPP coated electrodes.

Raman spectral method (Fig. 1C and 1D). The chemical structure of BSPP and the protein structure are mostly monitored by utilizing Raman spectroscopy [25-27]. Apart from FTIR spectroscopy, the binding process was monitored via Raman Spectroscopy. The Raman spectra showed that the -PNP- and -PN- bonding stretching vibrations of polymer BSPP backbone were observed at $718 \mathrm{~cm}^{-1}$ and $1168 \mathrm{~cm}^{-1}$ [18]. Raman spectroscopy is utilized to show amide bonds in protein structure. The bands of amide I, II and III bonds are found between $1650-1680 \mathrm{~cm}^{-1}, 1480-1570 \mathrm{~cm}^{-1}$ and $1235-1300 \mathrm{~cm}^{-1}$, respectively [28]. The amide I bond was seen at 1666 $\mathrm{cm}^{-1}$ [29]. The amide II band is usually weak in Raman spectra, but the amide III band is generally more apparent [30]. As illustrated in Fig. 1D, amide II and amide III bonds were monitored at 1548 and $1363 \mathrm{~cm}^{-1}$, respectively [31, 32].

In addition, clean ITO sheet and P-PHP polymer functionalized ITO sheet were investigated by Energy Dis- persive X-Ray (SEM-EDX) for elemental mapping measurement. Fig. $1 \mathrm{E}$ and $1 \mathrm{~F}$ inset show the SEM image of the ITO sheet was utilized in mapping analysis. Fig. $1 \mathrm{E}$ and $1 \mathrm{~F}$ show the EDX spectrum of the clean electrodes and polymer BSPP coated electrode. The Oxygen $(\mathrm{O})$, Indium (In) and Tin (Sn) peaks from ITO layer on PET (polyethylenetereftalat) are seen at 0.5, 3.28 and $3.44 \mathrm{keV}$, respectively (Fig. 1E) [4, 33, 34]. As seen in Fig. 1F, EDX-mapping spectra of polymer BSPP coated electrode included Carbon (C), Oxygen (O), Nitrogen (N), Phosphorous (P), Indium (In) and Tin (Sn) elements. The phosphorous and nitrogen signal at 2.01 and $0.38 \mathrm{keV}$ proved to presence polymer BSPP. This image displayed that the $\mathrm{P}$ and $\mathrm{N}$ atoms were homogeneous distributed on the electrode surface.

\section{Electrochemical Characterization of the Bioelectrode}

EIS is an electroanalytical method to monitor electrochemical changes formed on the electrode surface [35, 36]. Fig. 2A shows the EIS spectra of different stages in immunosensor fabrication process. 

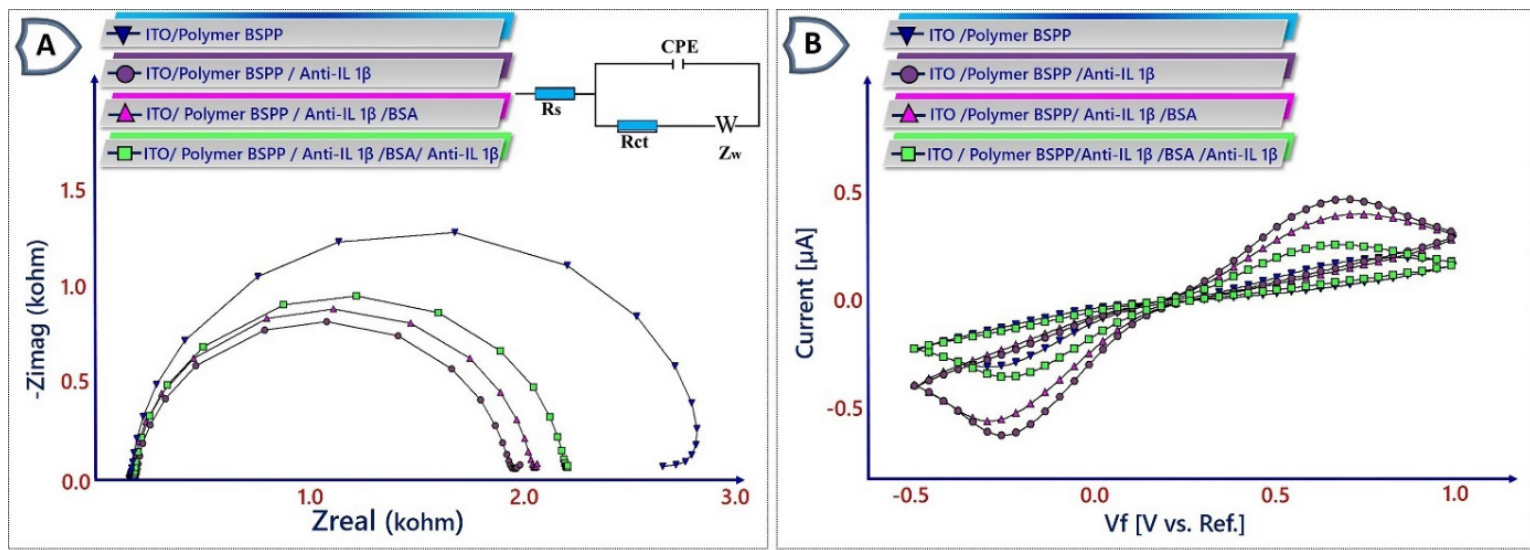

Figure 2. EIS spectra and cyclic voltammograms of the suggested biosensor.

The EIS data are fitted to a Randles equivalent circuit (inset in Fig. 2A) that includes the electrolyte solution resistance (Rs), the charge transfer resistance (Rct), the constant phase element (CPE) and Warburg impedance (W).In the EIS spectra, the semicircle diameter corresponds to the Rct parameter of redox conversion of the electroactive couple $\left[\mathrm{Fe}(\mathrm{CN})_{6}\right] 3^{-/ 4-}$ on the ITO-PET surface at certain potential [37].

In this study, EIS and CV were utilized for characterization of immunosensor fabrication protocol. Figure $2 \mathrm{~A}$ shows EIS spectra of the modification process. After polymer BSPP film coating on the disposable ITO sheet, a large semicircle diameter and also high Rct value was obtained. The high Rct value was the evidence of nonconductive layer formation.

After antibody immobilization process, decreases were seen in semicircle diameter of Nyquist plot and Rct value. Next, in the BSA blockage step an increase was monitored in Rct value due to BSA immobilization on the remaining aldehyde groups. As expected, Rct was further increased due to effective interaction between anti-IL $1 \beta$ antibody and IL $1 \beta$ antigen. The changes in the Rct values confirmed the fabrication protocol of the immunosensor. Figure $2 \mathrm{~B}$ illustrates the CVs of the proposed immunosensor. Obviously, low peak current was
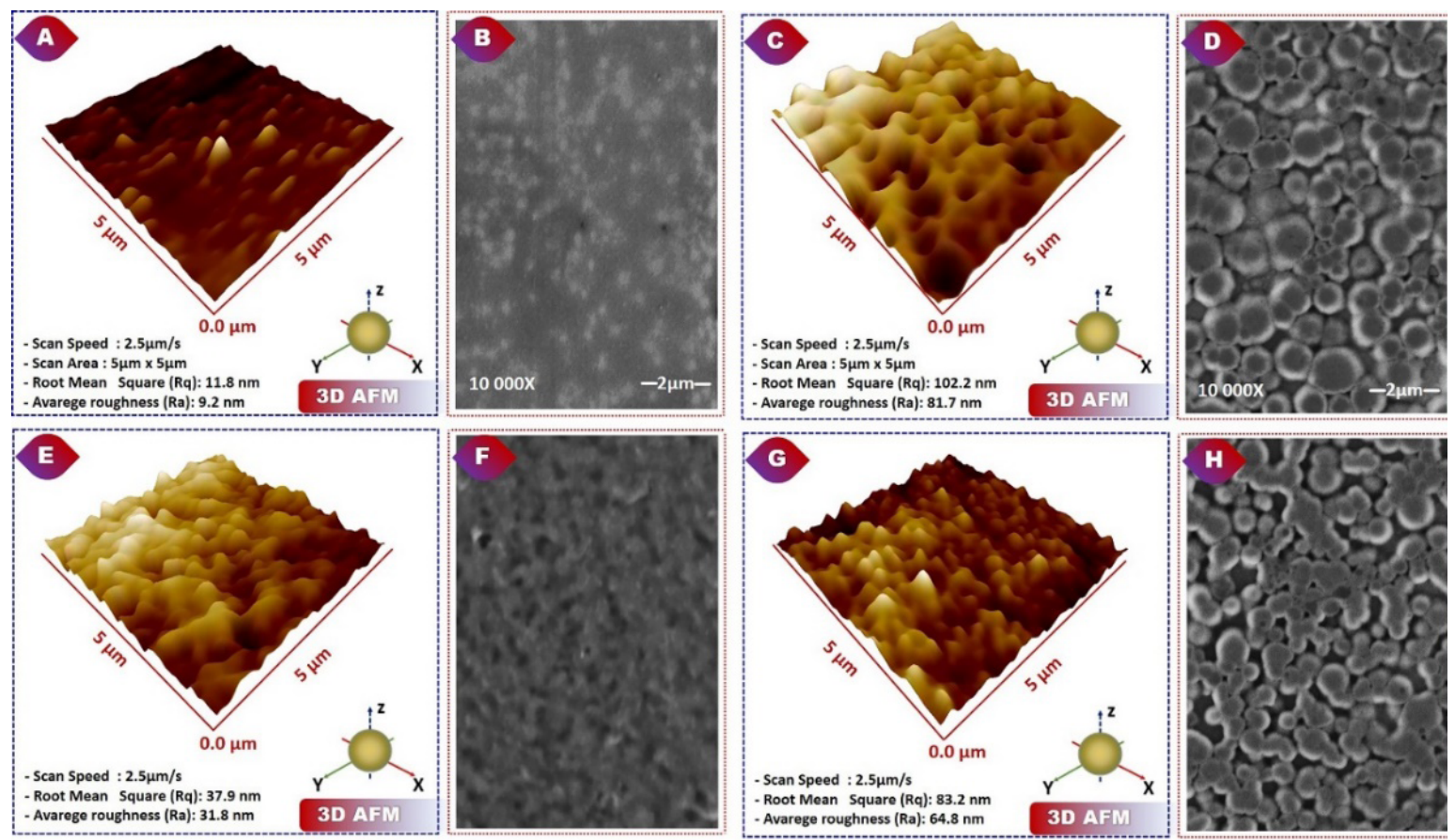

Figure 3. SEM and AFM images of ITO electrodes of the suggested biosensor. 

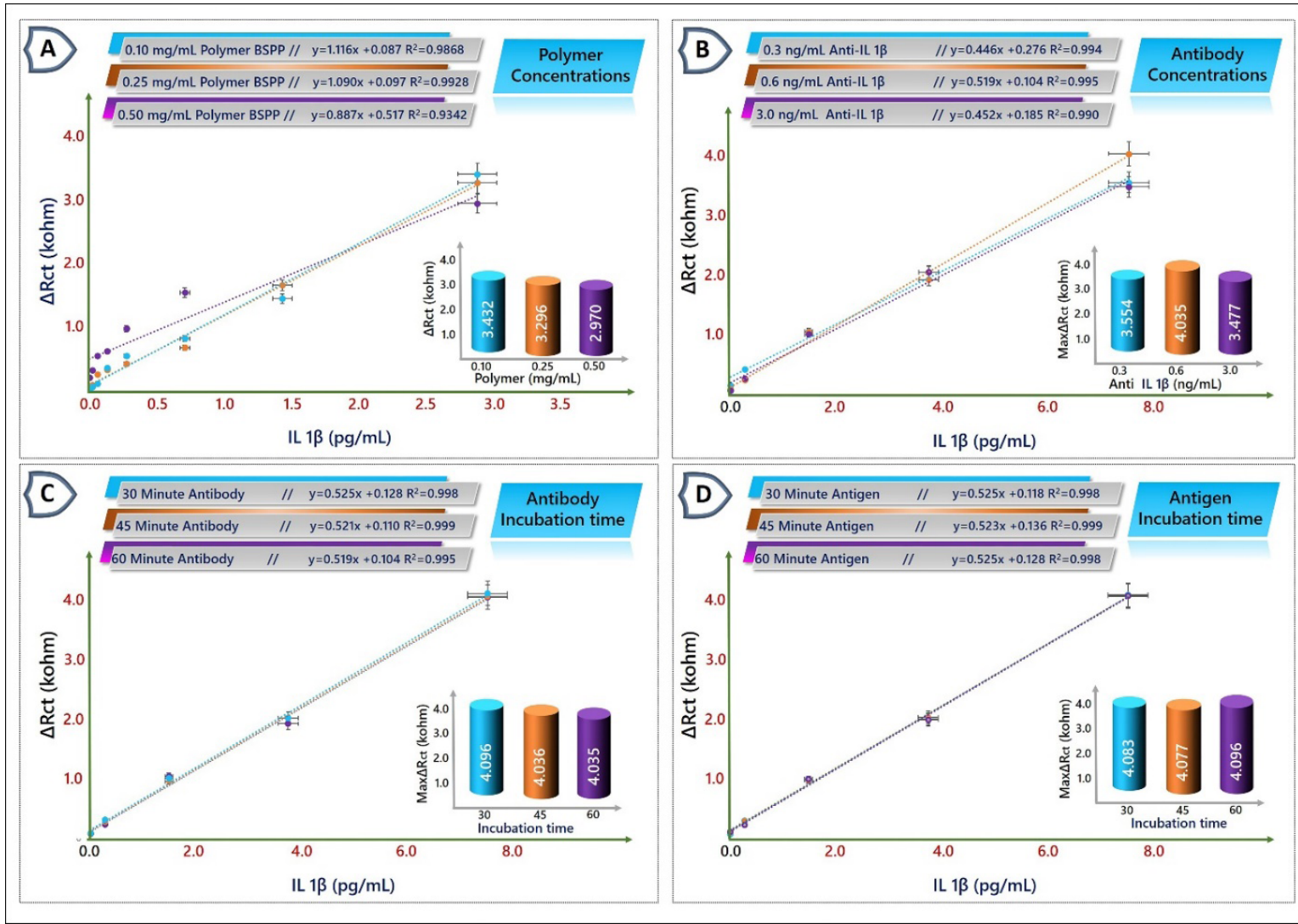

Figure 4. Optimization results (A) BSPP quantity, (B) anti- IL $1 \beta$ concentration, (C) anti- IL $1 \beta$ incubation duration, (D) IL $1 \beta$ antigen incubation duration.

seen after electrode coating with BSPP polymer modification due to nonconductivity property of polymer. The peak currents were increased after the anchoring of anti-IL $1 \beta$ antibodies. At the BSA blockage stage, decreases were seen in peak currents owing to blocking free aldehyde groups. Protein molecules inhibited electron transfer between electrode and electrolyte solution. Furthermore, the peak currents were decreased after attaching IL $1 \beta$ antigens thanks to the immunocomplexes formation. These findings proved the effective construction of the proposed biosensor.

\section{Morphological characterization of the suggested Biosensor}

Morphological characterization of the proposed immunoelectrodes was carreid out via SEM and AFM monitoring. After the polymer BSPP modification (Fig. $3 \mathrm{~A}$ and $3 B$ ), the electrode surface appeared like spherical grains and a uniform film was coated on the ITO electrode. Ra value of BSPP coated electrode was found as $9.2 \mathrm{~nm}$. In addition, as seen in Figure 3A, the ITO surface had densely porosity that proved a uniform ITO surface was formed for immobilizing of IL $1 \beta$ antibodies. Figure $3 C$ and 3D show the successful immobilization of anti- IL $1 \beta$ antibodies on the ITO substrate. As observed in Fig. $3 \mathrm{D}$, antibodies looked like granules. The Ra value of this step was measured as $81.7 \mathrm{~nm}$ (Figure 3C). After BSA immobilization, ITO electrode surface looked like a layer (Figure $3 \mathrm{E}$ and $3 \mathrm{~F}$ ). The Ra value of this stage was measured as $31.8 \mathrm{~nm}$. The immuno-interaction between anti-IL $1 \beta$ antibodies and IL $1 \beta$ antigens changed the ITO sheet surface (Figure $3 \mathrm{G}$ and $3 \mathrm{H}$ ). In this step, the Ra value was found as $64.8 \mathrm{~nm}$. The variations formed during the fabrication steps showed the successful fabrication.

\section{Optimization of the Immunosensor Conditions}

Immobilization matrix concentration, biorecognition element concentration and biomolecules incubation time are significant variables affecting the proposed immunosensor performance. Three different polymer concentrations were tried. As seen in Figure 4A, higher concentration of polymer BSPP caused low signals and maximum signal was attained when $0.1 \%$ polymer was employed. To optimize antibody concentration, three 

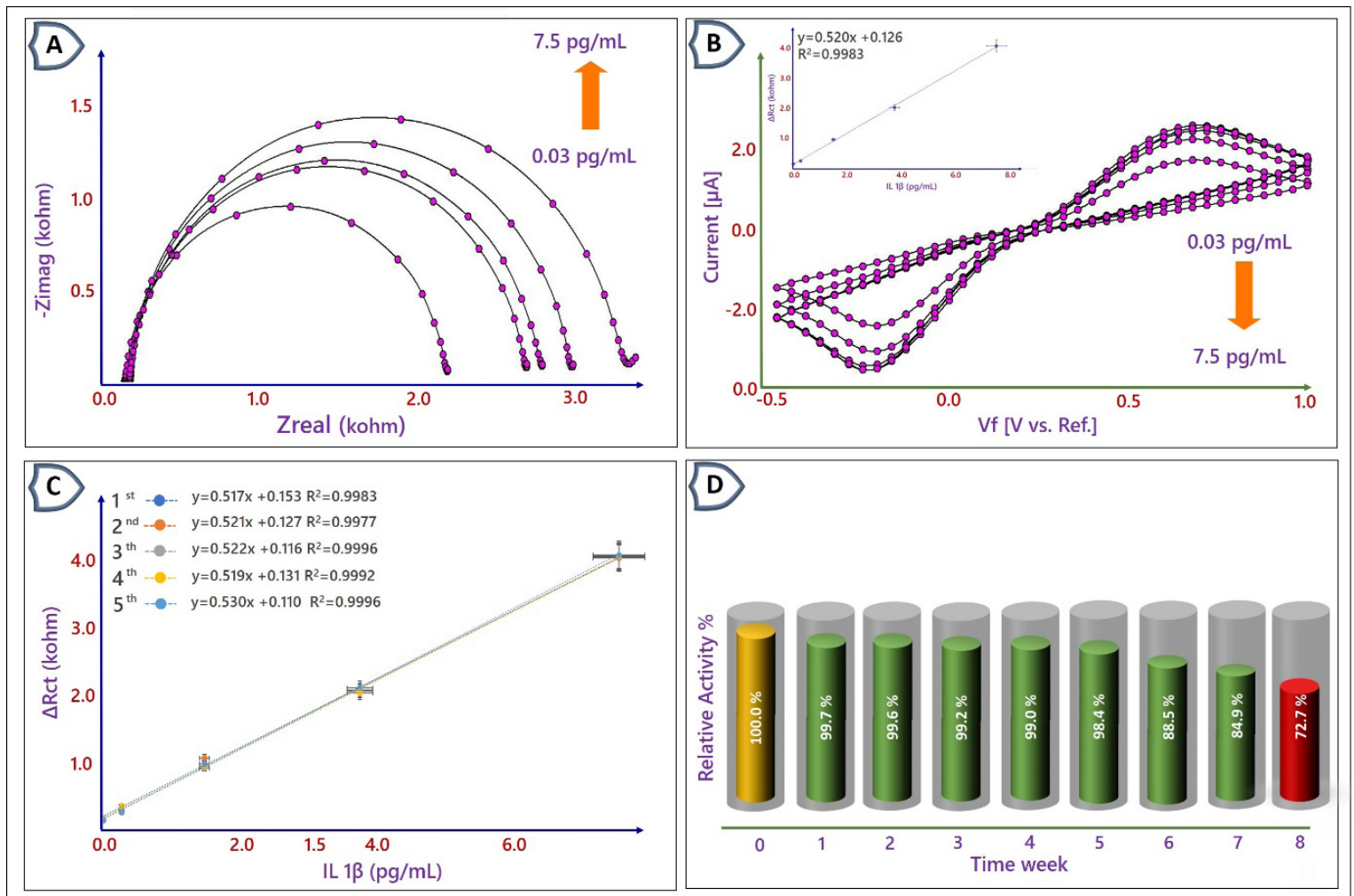

Figure 5. EIS (A) and CV (B) results of the biosensor for the determination of IL $1 \beta$ biomarker (from 0.03 to $7.5 \mathrm{pg} / \mathrm{mL}$ ), calibration plot (inset). Reproducibility (C), Storage stability (D) of the biosensor.

different concentration $(0.3 \mathrm{ng} / \mathrm{mL}, 0.6 \mathrm{ng} / \mathrm{mL}, 3 \mathrm{ng} /$ $\mathrm{mL}$ ) were utilized. At low concentration of antibody $(0.3$ $\mathrm{ng} / \mathrm{mL}$ ), a low signal was found. This concentration was not enough for IL $1 \beta$ detection. When $3 \mathrm{ng} / \mathrm{mL}$ anti-IL $1 \beta$ was employed, a low signal was measured. However, maximum signal was obtained when $0.6 \mathrm{ng} / \mathrm{mL}$ anti-IL $1 \beta$ antibody was used. Because of this, $0.6 \mathrm{ng} / \mathrm{mL}$ anti-IL $1 \beta$ antibody selected optimum level (Figure $4 \mathrm{~B}$ ). In order to optimize antibody and antigen incubation duration, three different incubation durations ( $30 \mathrm{~min}, 45 \mathrm{~min}, 60$ $\mathrm{min}$ ) were studied. The responses were similar at these durations. Maximum signals were obtained at $30 \mathrm{~min}$ incubation in antibody and antigen solutions and therefore, 30 min was chosen as optimal incubation time (Figure 4C and 4D). The other experiments were made by using these optimal conditions.

\section{Analytical Performance of the Suggested Biosensor}

In this study, EIS technique was used to examine the IL $1 \beta$ levels on the fabricated biosensor. Figure $5 \mathrm{~A}$ illustrates the EIS spectra of IL $1 \beta$ concentrations from 0.03 to $7.5 \mathrm{pg} / \mathrm{mL}$ under optimal experimental conditions. As shown in Figure $5 \mathrm{~A}$, the diameter of Nyquist plots increased with the enlarged IL $1 \beta$ concentrations. In contrast to increases in diameters, decreases were seen in peak currents (Figure 5B). The detection and quantification limit were calculated as $9.3 \mathrm{fg} / \mathrm{mL}$ and $31 \mathrm{fg} / \mathrm{mL}$, respectively. Figure $5 \mathrm{~A}$ inset illustrates the calibration plot of the suggested biosensor and the regression equation was $y=0.520[$ IL $1 \beta]+0.126$ with a correlation coefficient of 0.99 .

\section{Repeatability, Reproducibility and Stability}

In order to investigate the repeatability of the biosensor, 10 immunoelectrodes were prepared for IL $1 \beta$ antigen $(1.5 \mathrm{pg} / \mathrm{mL})$ detection under same conditions. The relative standard deviation (RSD) of the repeatability test was found as $1.56 \%$. In addition, to test the reproducibility of the biosensor, five biosensors were constructed, and the obtained results were seen in Figure 5C. The RSD value was found as $1.82 \%$, that indicated excellent reproducibility of the biosensor.

For stability test, the proposed immunoelectrodes were stored at $4 \mathrm{oC}$ and their activities were measured every week. As illustrate figure 5D, the impedance response was reduced by $72.7 \%$ after 8 weeks storage, demonstrating its long-term stability. 
Table 1. A) Biosensors for IL-1 $\beta$, B) Serum experiments.

\begin{tabular}{|c|c|c|c|}
\hline $\begin{array}{l}\text { A) Biosensor construction } \\
\text { step }\end{array}$ & Linear Range & Limit of Detection & Ref. \\
\hline $\begin{array}{c}\text { Eight gold working } \\
\text { microelectrodes } \\
\text { /4carboxymethylaryldiazonium / } \\
\text { antibodies/BSA }\end{array}$ & $1-15 \mathrm{pg} / \mathrm{mL}$ & $\begin{array}{l}0.3 \mathrm{pg} / \mathrm{mL} \\
0.7 \mathrm{pg} / \mathrm{mL}\end{array}$ & [38] \\
\hline $\begin{array}{c}\mathrm{N}_{2} \mathrm{O} \text { plasma modified silicon } \\
\text { nanowire /APTES/ } \\
\text { glutaraldehyde/DNA }\end{array}$ & $175 \mathrm{fg} / \mathrm{mL}-175 \mathrm{ng} / \mathrm{mL}$ & $43.75 \mathrm{fg} / \mathrm{mL}$ & {$[7]$} \\
\hline $\begin{array}{l}\text { Gold nanoparticles modified fiber } \\
\text { optic particle plasmon resonance } \\
\text { sensor/antibodies }\end{array}$ & $0.05-10 \mathrm{ng} / \mathrm{mL}$ & $21 \mathrm{pg} / \mathrm{mL}$ & [39] \\
\hline $\begin{array}{l}\text { Dual screen-printed carbon } \\
\text { electrodes modified with } \\
\text { 4-carboxyphenyl-functionalized } \\
\text { double-walled carbon } \\
\text { nanotubes/antibodies }\end{array}$ & $0.5-100 \mathrm{pg} / \mathrm{mL}$ & $0.38 \mathrm{pg} / \mathrm{mL}$ & [8] \\
\hline $\begin{array}{l}\text { Polymer BSPP modified ITO } \\
\text { electrode/anti-IL-1B/BSA }\end{array}$ & $0.03-7.5 \mathrm{pg} / \mathrm{mL}$ & $9.3 \mathrm{fg} / \mathrm{mL}$ & This work \\
\hline
\end{tabular}

\begin{tabular}{cccccc}
\hline B) Sample & $\begin{array}{c}\text { Found by the } \\
\text { biosensor } \\
(\mathrm{pg} / \mathrm{mL})\end{array}$ & $\begin{array}{c}\text { Added IL } 1 \beta \beta \\
\text { amount }(\mathrm{pg} / \mathrm{mL}) \\
\text { Total found }\end{array}$ & Total Found & \% Recovery & $\begin{array}{c}\text { \% Relative } \\
\text { Difference }\end{array}$ \\
\hline Human Serum 1 & 0.41 & 0.2 & 0.68 & 102.60 & 2.60 \\
\hline Human Serum 2 & 0.50 & 0.2 & 0.76 & 100.76 & 0.76 \\
\hline Human Serum 3 & 0.43 & 0.2 & 0.69 & 100.83 & 0.83 \\
\hline Human Serum 4 & 0.34 & 0.2 & 0.59 & 100.31 & 0.31 \\
\hline Human Serum 5 & 0.48 & 0.2 & 0.73 & 100.25 & 0.25 \\
\hline
\end{tabular}

\section{Analysis of Real Human Serum Samples}

In order to investigate the practical applicability of the biosensor, the IL $1 \beta$ antigen concentration was measured in real human serum samples. In addition, standard addition method was utilized to calculate the recovery of the method. As seen Table 1B, the recovery ranges were from $100.25 \%$ to $102.60 \%$, that confirmed the applicability of the biosensor for IL $1 \beta$ determination.

\section{CONCLUSION}

To sum up. BSPP polymer was synthesized by using ring opening polymerization and replacement reaction. Then. it was applied to disposable ITO sheet and BSPP modified ITO substrate was used as a working electrode in biosensing system. In this biosensing system. anti-IL $1 \beta$ antibodi es were employed as biorecognition elements and the basic principle of this biosensing system was based on immuno-interaction between anti-IL $1 \beta$ antibodies and IL $1 \beta$ antigens. The immunosensor illustrated a wide linear range of $0.03-7.5 \mathrm{pg} / \mathrm{mL}$. with a low detection limit of $9.3 \mathrm{fg} / \mathrm{mL}$ (Signal/Noise=3). As reported in table $1 \mathrm{~A}$, the LOD and linear detection range of our developed immunosensor is better than that of other IL-1 $\beta$ sensor reported in the literature. The high sensitivity and wide linear detection range of the suggested immunosensor can be attributed to the uniform polymer film formation. Moreover. it had an excellent reproducibility. good selectivity and long-term stability. The proposed immunosensor had success in human serum for IL $1 \beta$ detection and it had good recovery (100.25\%-102.60\%). The obtained results illustrated that this immunosensor was a promising tool for IL $1 \beta$ detection. 


\section{References}

1. S. Kumar, R.K. Singh, R. Murthy, T. Bhardwaj, Synthesis and evaluation of substituted poly (organophosphazenes) as a novel nanocarrier system for combined antimalarial therapy of primaquine and dihydroartemisinin, Pharm. Res., 32 (8) (2015) 2736-2752.

2. H.R. Allcock, The synthesis of functional polyphosphazenes and their surfaces, Appl. Organomet. Chem., 12 (10-11) (1998) 659-666.

3. J. Dudás, A. Fullár, M. Bitsche, V. Schartinger, I. Kovalszky. G.M. Sprinzl, H.J.E.c.r. Riechelmann, Tumor-produced. active Interleukin-1 $\beta$ regulates gene expression in carcinomaassociated fibroblasts, Exp. Cell. Res., 317 (2011) 2222-2229.

4. E.B. Aydın, M. Aydın, M.K. Sezgintürk, Highly sensitive electrochemical immunosensor based on polythiophene polymer with densely populated carboxyl groups as immobilization matrix for detection of interleukin $1 \beta$ in human serum and saliva, Sens. Actuator. B, 270 (2018) 18-27.

5. E.B. Aydın, M.K. Sezgintürk, A disposable and ultrasensitive ITO based biosensor modified by 6-phosphonohexanoic acid for electrochemical sensing of IL-1 $\beta$ in human serum and saliva, Anal. Chim. Acta, 1039 (2018) 41-50.

6. C.E. Krause, B.A. Otieno, G.W. Bishop, G. Phadke, L. Choquette, R.V. Lalla, D.E. Peterson, J.F. Rusling, Ultrasensitive microfluidic array for serum pro-inflammatory cytokines and C-reactive protein to assess oral mucositis risk in cancer patients, Anal. Bioanal. Chem., 407 (2015) 7239-7243.

7. C.-Y. Chiang, M.L. Hsieh, K.W. Huang, L.K. Chau, C.M. Chang, S.-R. Lyu, Fiber-optic particle plasmon resonance sensor for detection of interleukin-1 $\beta$ in synovial fluids, Biosens. Bioelectron., 26 (2010) 1036-1042.

8. A. Baraket, M. Lee, N. Zine, M. Sigaud, J. Bausells, A. Errachid, A fully integrated electrochemical biosensor platform fabrication process for cytokines detection, Biosens. Bioelectron., 93 (2017) 170-175.

9. J. Amani, M. Maleki, A. Khoshroo, A. Sobhani-Nasab, M. Rahimi-Nasrabadi, An electrochemical immunosensor based on poly p-phenylenediamine and graphene nanocomposite for detection of neuron-specific enolase via electrochemically amplified detection, Anal. Biochem., 548 (2018) 53-59.

10. M. Aydın, E.B. Aydın, M.K. Sezgintürk, A disposable immunosensor using ITO based electrode modified by a star-shaped polymer for analysis of tumor suppressor protein p53 in human serum, Biosens. Bioelectron., 107 (2018) 1-9.

11. P. Khashayar, G. Amoabediny, B. Larijani, M. Hosseini, J. Vanfleteren, Fabrication and Verification of Conjugated AuNP-Antibody Nanoprobe for Sensitivity Improvement in Electrochemical Biosensors, Sci. Rep., 7 (2017) 16070.

12. N.S. Ferreira, M.G.F. Sales, Disposable immunosensor using a simple method for oriented antibody immobilization for label-free real-time detection of an oxidative stress biomarker implicated in cancer diseases, Biosens. Bioelectron., 53 (2014) 193-199.

13. E.B. Aydın, M. Aydın, M.K. Sezgintürk, Electrochemical immunosensor based on chitosan/conductive carbon black composite modified disposable ITO electrode: An analytical platform for p53 detection, Biosens. Bioelectron., 121 (2018) 80-89.

14. E.B. Aydın, M.K. Sezgintürk, Indium Tin Oxide (ITO): A promising material in biosensing technology TrAC. Trends Anal. Chem., 97 (2017) 309-315.
15. M. Aydın, E.B. Aydın, M.K. Sezgintürk, A highly selective electrochemical immunosensor based on Conductive Carbon Black and Star PGMA polymer composite material for IL-8 biomarker detection in human serum and saliva, Biosens. Bioelectron., 117 (2018) 720-728.

16. K. Ghayedi Karimi, S.A. Mozaffari, M. Ebrahimi, Spin-coated $\mathrm{ZnO}$-graphene nanostructure thin film as a promising matrix for urease immobilization of impedimetric urea biosensor, J. Chin. Chem. Soc., 65 (2018) 1379-1388.

17. M. Aydın, E.B. Aydın, M.K. Sezgintürk, Bioelectronics. Electrochemical immunosensor for $\mathrm{CDH} 22$ biomarker based on benzaldehyde substituted poly (phosphazene) modified disposable ITO electrode: A new fabrication strategy for biosensors, Biosens. Bioelectron., 126 (2019) 230-239.

18. G.A. Carriedo, F.J. García Alonso, P.A. González, J.R. Menéndez, Infrared and Raman spectra of the phosphazene high polymer $\left[\mathrm{NP}\left(\mathrm{O}_{2} \mathrm{C}_{12} \mathrm{H}_{8}\right)\right] \mathrm{n}$, J. Raman Spect., 29 (1998) 327-330.

19. C. Fiedler, B. Luerssen, B. Lucht, J. Janek, Synthesis and characterization of polyphosphazene electrolytes including cyclic ether side groups, J. Power Sourc., 384 (2018) 165-171.

20. T.A. Luther, F.F. Stewart, J.L. Budzien, R.A. LaViolette, W.F. Bauer, M.K. Harrup, C.W. Allen, A. Elayan, On the mechanism of ion transport through polyphosphazene solid polymer electrolytes: NMR. IR. and Raman spectroscopic studies and computational analysis of $15 \mathrm{~N}$-labeled polyphosphazenes, J. Phy. Chem. B, 107 (2003) 3168-3176.

21. L. Daasch, D. Smith, Infrared spectra of phosphorus compounds, Anal. Chem., 23 (1951) 853-868.

22. H. Allcock, R. Kugel, K. Valan, Phosphonitrilic compounds. VI. High molecular weight poly (alkoxy-and aryloxyphosphazenes), Inorg. Chem., 5 (1966) 1709-1715.

23. P. Jiang, X. Gu, S. Zhang, J. Sun, R. Xu, S. Bourbigot, S. Duquesne, M. Casetta, Flammability and thermal degradation of poly (lactic acid)/polycarbonate alloys containing a phosphazene derivative and trisilanollsobutyl POSS, Polymer, 79 (2015) 221-231.

24. A. Banas, K. Banas, A. Furgal-Borzych, W. Kwiatek, B. Pawlicki, $M$. Breese, The pituitary gland under infrared light-in search of a representative spectrum for homogeneous regions, Analyst, 140 (2015) 2156-2163.

25. M. Chen, R. Lord, Laser-excited Raman spectroscopy of biomolecules. VI. Polypeptides as conformational models, J. Am. Chem. Soc., 96 (1974) 4750-4752.

26. K. Chrabaszcz, K. Kochan, A. Fedorowicz, A. Jasztal, E. Buczek, L.S. Leslie, R. Bhargava, K. Malek, S. Chlopicki, K.M. Marzec, FT-IR-and Raman-based biochemical profiling of the early stage of pulmonary metastasis of breast cancer in mice, Analyst, 143 (2018) 2042-2050.

27. K. Dégardin, A. Desponds, Y. Roggo, Protein-based medicines analysis by Raman spectroscopy for the detection of counterfeits, Forensic Sci. Int., 278 (2017) 313-325.

28. T. Kitagawa, S. Hirota, Raman spectroscopy of proteins Handbook of Vibrational Spectroscopy, New York: Wiley. 2006.

29. A. Bonifacio, C. Beleites, F. Vittur, E. Marsich, S. Semeraro, S. Paoletti, V. Sergo, Chemical imaging of articular cartilage sections with Raman mapping. employing uni-and multivariate methods for data analysis, Analyst, 135 (2010) 31933204.

30. R.S. Jakubek, J. Handen, S.E. White, S.A. Asher, I.K. Lednev, Ultraviolet resonance Raman spectroscopic markers for protein structure and dynamics, TrAC. Trends Anal. Chem., 103 (2017) 223-229. 
31. J. Lippert, D. Tyminski, P. Desmeules, Determination of the secondary structure of proteins by laser Raman spectroscopy, J. Am. Chem. Soc., 98 (1976) 7075-7080.

32. R.W. Williams, Protein secondary structure analysis using Raman amide I and amide III spectra, Methods in enzymology., Elsevier 1986. pp. 311-331.

33. E.B. Aydın, M. Aydın, M.K. Sezgintürk, A highly sensitive immunosensor based on ITO thin films covered by a new semi-conductive conjugated polymer for the determination of TNFa in human saliva and serum samples, Biosens. Bioelectron., 97 (2017) 169-176.

34. H. Sabouri, K. Ohno, S. Perrier, Well-defined colloidal crystal films from the 2D self-assembly of core-shell semi-soft nanoparticles, Poly. Chem., 6, (2015) 7297-7307.

35. F. Mollarasouli, V. Serafín, S. Campuzano, P. Yáñez-Sedeño, J.M. Pingarrón, K. Asadpour-Zeynali, Ultrasensitive determination of receptor tyrosine kinase with a label-free electrochemical immunosensor using graphene quantum dots-modified screen-printed electrodes, Anal. Chim. Acta, 1011 (2018) 28-34.
36. H.B. Wang. H.D. Zhang. S.P. Xu. T. Gan. K.J. Huang. Y.M. Liu, A sensitive and label-free electrochemical impedance biosensor for protein detection based on terminal protection of small molecule-linked DNA, Sens. Actuator. B, 194 (2014) 478-483.

37. Y. Chen, B. Jiang, Y. Xiang, Y. Chai, R. Yuan, Target recycling amplification for sensitive and label-free impedimetric genosensing based on hairpin DNA and graphene/Au nanocomposites, Chem. Commun., 47 (2011) 12798-12800.

38. G.I. Kim, K.W. Kim, M.K. Oh, Y.M. Sung, Electrochemical detection of vascular endothelial growth factors (VEGFs) using VEGF antibody fragments modified Au NPs/ITO electrode, Biosens Bioelectron., 25 (2010) 1717-1722.

39. J.Y. Wu, C.L. Tseng, Y.K. Wang, Y. Yu, K.L. Ou, C.C. Wu, Detecting interleukin-1 $\beta$ genes using a N2O plasma modified silicon nanowire biosensor, J. Exp. Clin. Med., 5 (2013) 12-16. 